\title{
Potential Eutrophication Associated with Phosphorus Inputs from Shrimp Effluents in a Tropical Estuary
}

Rafael Fernando Oliveira Aquino' Susan Waleska Pequeno Rodrigues ${ }^{2}$ Pedro Walfir Martins Souza-Filho ${ }^{3}$ Silvia Keiko Kawakami ${ }^{4}$

\author{
${ }^{1}$ Universidade Federal do Pará \\ Instituto de Geociências, \\ Programa de Pós-graduação em Geologia e \\ Geoquímica \\ Rua Augusto Corrêa, 01 \\ Campus Guamá \\ Belém PA Brasil \\ CEP: $66075-110$ \\ ${ }^{2}$ Instituto de Geociências \\ Universidade de Brasília \\ Asa Norte \\ Brasília DF Brasil \\ CEP: 70910900 \\ ${ }^{3}$ Instituto Tecnológico Vale \\ Rua Boaventura da Silva, 955 \\ Rua Boav
Nazaré, \\ Belém PA Brasil \\ CEP 66055-090 \\ ${ }^{4}$ Universidade Federal do Pará \\ Instituto de Geociências \\ Faculdade de Oceanografia \\ Campus Guamá \\ Rua Augusto Corrêa, 01 \\ Belém PA Brasil \\ CEP: $66075-110$ \\ *Corresponding author: \\ skawakami@ufpa.br
}

Copyright

This is an open-access article distributed under the terms of the Creative Commons Attribution License.

\section{RESUMO}

A carcinicultura tem sido associada à eutrofização devido à geração de efluentes enriquecidos com matéria orgânica e nutrientes. A distribuição de fósforo $(\mathrm{P})$ foi investigada no Estuário do Rio Coreaú (NE do Brasil) usando-se sedimentos superficiais e testemunhos. Nos sedimentos superficiais, as concentrações totais de $\mathrm{P}$ variaram de 349,2 a 633,5 $\mu \mathrm{g} \mathrm{g}^{-1}$ (média de 465,2 $\mu \mathrm{g} \mathrm{g}^{-1}$ ) e foram cerca de três vezes menores do que as de outros estuários brasileiros impactados por culturas maiores de camarão. A predominância das formas de $\mathrm{P}$ nos sedimentos superficiais apresentou a sequência: $\mathrm{P}$ ligado ao ferro (Fe-P, 30\%) > P orgânico $($ Org-P, $23 \%)>\mathrm{P}$ trocável (Exch-P, 20\%) > autigênico apatita $(\mathrm{Ca}-\mathrm{P}, 15 \%)>$ apatita detrital (De-P, 12\%). Nenhuma correlação significativa foi observada entre o Exch-P e o Fe-P $(r=0.389 ; \mathrm{p}<0.05)$. As maiores concentrações de Exch$\mathrm{P}$ e Org-P e uma forte correlação entre essas formas $(\mathrm{r}=0,706 ; \mathrm{p}<0,05)$, sugerem as mesmas fontes de $\mathrm{P}$ e matéria orgânica. Os testemunhos apresentaram concentrações de $\mathrm{P}$ total de10,211 e $15,632 \mu \mathrm{g} \mathrm{g}^{-1}$ na foz e no estuário superior, respectivamente. T1 exibiu a sequência predominante: De-P $(36 \%)>\mathrm{Ca}-\mathrm{P}(25 \%)$ $>\mathrm{Fe}-\mathrm{P}(22 \%)>$ Exch-P $(9 \%)>$ Org-P $(7 \%)$; enquanto T2 revelou: $\mathrm{Fe}-\mathrm{P}(31 \%)>$ De-P $(23 \%)>$ Org-P $(21 \%)>$ Ca-P $(17 \%)>$ Exch-P $(9 \%)$. O histórico deposicional de $\mathrm{P}$ indica episódios de acumulação de $\mathrm{P}$ no final de 1980 e meados de 1990, coincidentes com o aumento da urbanização e início ou máximo de atividade das fazendas de camarão. Apesar das baixas concentrações de $\mathrm{P}$ total, as maiores proporções das formas lábeis Exch-P, Fe-P e Org-P nos sedimentos superficiais indicaram uma tendência a um alto potencial de eutrofização.

Palavras-chave: nutrientes, fracionamento de fósforo, aquicultura, estuário do rio Coreaú

\section{ABSTRACT}

Shrimp farming has been associated with eutrophication due to the generation of effluents enriched with organic matter and nutrients. Phosphorus (P) distribution was investigated in the Coreaú River Estuary (NE Brazil) using surface sediments and sediment cores. In surface sediments, total $\mathrm{P}$ concentrations ranged from 349.2 to $633.5 \mu \mathrm{g} \mathrm{g}^{-1}$ (mean $\left.=465.2\right)$ and were about three times lower than those of other Brazilian estuaries impacted by larger shrimp cultures. The predominance of $\mathrm{P}$ forms in surface sediments followed the sequence: iron-bound $\mathrm{P}(\mathrm{Fe}-\mathrm{P}, 30 \%)>$ organic-P (Org-P, 23\%) > exchangeable-P (Exch-P, 20\%) > authigenic apatite $(\mathrm{Ca}-\mathrm{P}, 15 \%)>$ detrital apatite (De-P, 12\%). No significant correlation was observed between Exch-P and Fe-P $(r=0.389 ; p<0.05)$. Highest Exch-P and Org-P concentrations and a strong correlation between these forms were found $(r=0.706, p<0.05)$, suggesting the same sources of $P$ and organic matter. Total $\mathrm{P}$ accumulation along the cores was 10,211 and $15,632 \mu \mathrm{g} \mathrm{g}^{-1}$ at the estuary mouth (T1) and the upper estuary (T2), respectively. T1 exhibited the predominant sequence: De-P $(36 \%)>\mathrm{Ca}-\mathrm{P}(25 \%)>\mathrm{Fe}-\mathrm{P}(22 \%)>$ Exch-P $(9 \%)>$ Org-P (7\%); whereas T2 showed: Fe-P $(31 \%)>$ De-P $(23 \%)>$ Org-P $(21 \%)>$ Ca-P (17\%) > Exch-P (9\%). Phosphorus depositional history points to $\mathrm{P}$ accumulation episodes at the end of the 1980 and mid-1990, coinciding with increasing urbanization and the beginning or maximum activity of the shrimp farms. Despite the low total $\mathrm{P}$ concentrations, the proportions of the labile forms Exch-P, Fe-P and Org-P in surface sediments indicated a trend to a high potential for eutrophication.

Keywords: nutrients, P fractionation, aquaculture, Coreaú River Estuary 


\section{INTRODUCTION}

Aquaculture has shown a growing importance in the world fish production with an increasing global market share from 13.4 to 42.2\%, since 1990 until 2012 (FAO, 2014). According to more recent data, Brazilian total aquaculture has been estimated at 800,000 tonnes (VALENTI et al., 2021) from which 77,000 tonnes resulted from shrimp production (ABCC, 2019). Around 3,000 shrimp farms, concentrated mainly in the northeastern states Ceará and Rio Grande do Norte, are responsible for this production (VALENTI et al., 2021). Although a relevant practice for the generation of local employments, shrimp farming has been associated with severe environmental impacts of natural water bodies mainly as a consequence of nutrient inputs from the untreated effluents of the shrimp tanks (PÁEZ-OSUNA, 2001).

The behavior of nutrients in sediments, particularly that of phosphorus $(\mathrm{P})$, has been investigated to track biogeochemical changes and to identify the potential to eutrophication of an area under the impact of aquaculture (e.g. NÓBREGA et al., 2014, ZHUANG et al., 2014). Dissolved inorganic phosphorus (DIP) is the preferential form assimilated by aquatic organisms. DIP can be associated with iron, calcium, aluminum, clay and organic compounds (MCKELVIE, 2005), and thus be transported or deposited in sediments. Such Pcompounds remain buried in bottom sediments or return to the overlying water through the sediment-water interface and are controlled by biological, physical and chemical processes (BOSTROM et al., 1988). The most labile sedimentary $\mathrm{P}$ forms are the exchangeable or

\section{MATERIAL AND METHODS}

The Coreaú River Estuary is located on the west coast of the Ceará State, Brazil. According to the Köppen-Geiger classification, the area has a hot and semiarid climate type (Aw), with a short and irregular rainy season, and an intense and lasting dry season (PEEL et al., 2007). Air temperature varies from 26 to $28^{\circ} \mathrm{C}$ and rainfall precipitation ranges from 0.0 to $122.3 \mathrm{~mm}$ (ANA, 2013). Coreaú River discharge decays rapidly from 32 to less than 1 $\mathrm{m}^{3} \mathrm{~s}^{-1}$ from the rainy to dry season (MOLISANI et al., 2006).

Glassware and plastic bottles used for sampling, extraction and analysis were soaked loosely sorbed phosphorus (Exch-P), ironbound phosphorus (Fe-P) and organic phosphorus (Org-P) and are susceptible to variations in redox conditions, decomposition of organic matter and sediment resuspension (RUTTENBERG; BERNER, 1993; SAMADIMAYBODI et al., 2013). The detrital apatite (De-P) and the sum of authigenic apatite, $\mathrm{CaCO}_{3}$-bound $\mathrm{P}$ and biogenic apatite $(\mathrm{Ca}-\mathrm{P})$ are more stable, and may be utilized as indication of the continental, marine, or estuarine contribution (MARINS et al., 2007).

In the catchment area of the Coreaú River Estuary (Ceará State, NE Brazil), shrimp farms occupied $10.8 \times 10^{6} \mathrm{~m}^{2}$ and delivered a production of 3,324 t y-1 until 2011 (ROCHA, 2017). In these farms, approximately $0.1 \mathrm{t} \mathrm{y}^{-1}$ of triple superphosphate, $\mathrm{Ca}\left(\mathrm{H}_{2} \mathrm{PO}_{4}\right)_{2} \times \mathrm{H}_{2} \mathrm{O}$, was applied as fertilizers and resulted in effluents with mean total phosphorus concentrations of $0.20 \mathrm{mg} \mathrm{L}^{-1}$, which were twofold higher than those allowed by the Brazilian legislation (ROCHA, 2017). Nevertheless, field data regarding nutrient biogeochemistry are scarce in such estuarine areas and hamper our understanding on the environmental functioning that could help us to achieve more sustainable aquaculture practices. In the present study we evaluate $\mathrm{P}$ accumulation in surface sediments in the vicinities of shrimp farms installed in a mangrove area and the eutrophication potential of the Coreaú River Estuary. The depositional history of $\mathrm{P}$ within the estuary was traced back using two sediment cores as an approach for the identification of the dynamics and possible anthropogenic effects.

in $\mathrm{HCl}$ solution $(10 \% \mathrm{v} / \mathrm{v})$ over a $24 \mathrm{~h}$ period and then rinsed four times with deionized water. Sediment sampling was performed during October 2012 (dry season). Five surface sediment samples (S1, S2, S3, S4 and S5) were collected with stainless steel spatula in different points along the estuary. Two sediment cores ( $\mathrm{T} 1$ and $\mathrm{T} 2$ ) were obtained with the aid of PVC tubes $(10 \mathrm{~cm}$ diameter and 60 $\mathrm{cm}$ depth), and then sectioned into $2 \mathrm{~cm}$-layers (Fig. 1). All samples were stored in sealed plastic flasks and frozen until further analysis.

A modified SEDEX method (RUTTENBERG, 1992; HUERTA-DIAZ et 
al., 2005) was used for the separation and quantification of the five major $\mathrm{P}$ forms (Exch$\mathrm{P}, \mathrm{Fe}-\mathrm{P}, \mathrm{Ca}-\mathrm{P}, \mathrm{De}-\mathrm{P}$ and P-Org). In brief, all sediment samples were homogenized, dried at $60^{\circ} \mathrm{C}$ for $24 \mathrm{~h}$ (FILIPPELLI; DELANEY, 1996), and then the grains were selected using a $63 \mu \mathrm{m}$ sieve, which has been shown to improve the extraction efficiency for Exch-P and Fe-P fractions (ANDRIEUX-LOYER; AMINOT, 2001). Five hundred $\mathrm{mg}$ of sediments were used for the sequential extraction, following the extractant volume ratios and $\mathrm{pH}$ buffering proposed by Ruttenberg (1992). Extraction time to obtain Ca-P fraction was shortened by omitting the last washing steps with $\mathrm{MgCl}_{2}$ solution and water.
The extracts were analyzed with UV-Vis spectrophotometer, using the molybdenum blue method (HANSEN; KOROLEFF, 1999). Absorbances were measured at $880 \mathrm{~nm}$ within $30 \mathrm{~min}$ after reaction. Reagent blanks, calibration curves and $P$ recovery tests $(n=4)$ using a standard reference material (SRM 1646a, NIST) were performed for analytical quality assurance (Table 1). Total-P recovery and its standard deviation were $108.3 \%$ and 1.8 , respectively. The standard deviations obtained for Exch-P, Fe-P, Ca-P, De-P and Org-P were, respectively, 4.9; 5.2; 0.9; 2.6 and 2.6. Calibration curve for each $\mathrm{P}$ form was developed because changes in $\mathrm{pH}$ and extractant dilutions alter absorbance.

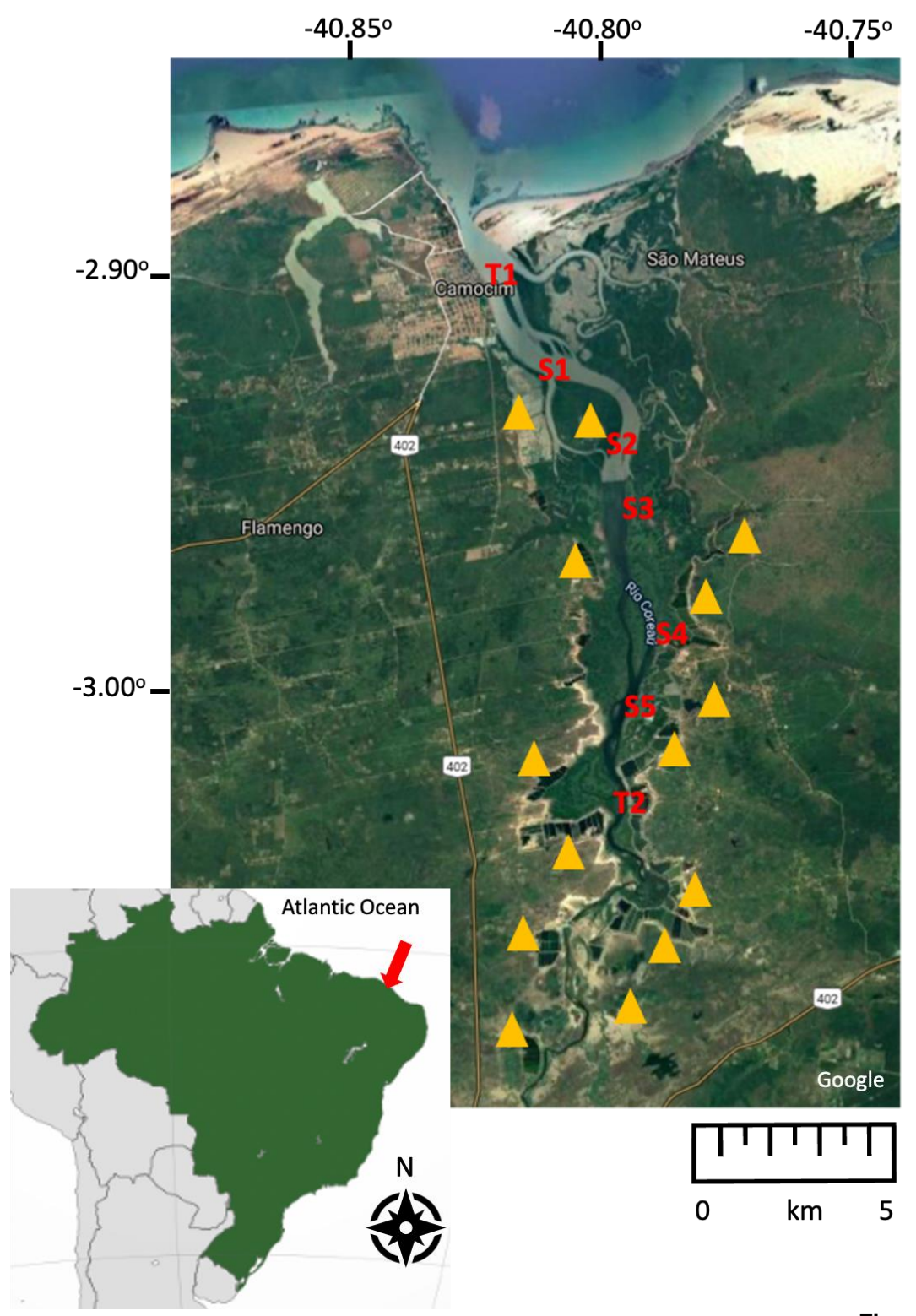

Sampling sites in the Coreaú River Estuary (Ceará, Brazil). T1 and T2 indicate the locations of the sediment cores and S1-S5, the surface sediment samples. Triangles indicate approximately shrimp farming areas along the estuary, according to Rodrigues 
Table 1 - Standard deviation (SD) and recovery percentage for each $\mathrm{P}$ form and of the Total-P.

\begin{tabular}{cccccccc}
\hline & Exch-P & Fe-P & Ca-P & De-P & Org-P & Total-P & Total-P Recovery (\%) \\
\hline SRM 1 & 1.1 & 4.8 & 1.0 & 1.3 & 1.3 & 9.5 & 109.3 \\
SRM 2 & 0.8 & 4.5 & 1.3 & 1.4 & 1.5 & 9.4 & 107.8 \\
SRM 3 & 0.8 & 4.4 & 1.5 & 1.3 & 1.5 & 9.4 & 108.2 \\
SRM 4 & 0.8 & 4.4 & 1.3 & 1.3 & 1.4 & 9.4 & 107.9 \\
\hline Mean & 0.9 & 4.6 & 1.3 & 1.3 & 1.4 & 9.4 & 108.3 \\
SD & 0.14 & 0.15 & 0.15 & 0.03 & 0.07 & 0.05 & 0.61 \\
\hline
\end{tabular}

Exch-P: Exchangeable-P; Fe-P: iron-bound-P; Ca-P: authigenic apatite $+\mathrm{CaCO}_{3}$-bound $\mathrm{P}+$ biogenic apatite; De-P: detrital-P; Org-P: organic-P.

Total organic carbon percentage (\% TOC) was obtained by a simple titrimetric method (GAUDETTE et al., 1974). Granulometric analysis was performed using a laser granulometer (Sedigraph $5100 \mathrm{X}$-ray) for the fine grains $(<63 \mu \mathrm{m}$, silt and clay). Sedimentation rates were determined using $\mathrm{Pb}-$
210 activities (NITTROUER, 1979) and the results were presented elsewhere (RODRIGUES, 2014). Statistical analysis employed was Pearson Correlation for surface sediments and cores samples using the OriginPro 9.2 software.

\section{RESULTS AND DISCUSSION}

\subsection{DISTRIBUTION OF P FORMS IN SURFACE SEDIMENTS}

The concentrations of the sedimentary $\mathrm{P}$ forms and \% TOC for the surface sediment samples of the Coreaú River Estuary are listed in Table 2. Total-P concentrations in surface sediments reached a minimum of 349.1 (S3) and a maximum of $633.4 \mu \mathrm{g} \mathrm{g}^{-1}(\mathrm{~S} 2)$, at sites closer to the marine end. The predominant $\mathrm{P}$ form in surface sediments was Fe-P, which accounted for $30 \%$ of the Total-P, and presented concentration range from 93.6 (S3) to $238.9 \mu \mathrm{g} \mathrm{g}^{-1}(\mathrm{~S} 2)$. The second major form was Org-P, corresponding to $23 \%$ of the Total$\mathrm{P}$ concentration, was found between 83.2 (S3) to $136.6 \mu \mathrm{g} \mathrm{g}^{-1}$ (S4). Exch-P was the third most dominant form and showed concentrations from 70.8 (S3) to $122 \mu \mathrm{g} \mathrm{g}^{-1}$ (S4), which represented up to $19 \%$ of the Total-P. The Ca$\mathrm{P}$ and De-P contributed less to the Total-P, with 15 and $11 \%$, respectively. Ca-P concentrations ranged from 53.3 (S5) to 99.7 $\mu \mathrm{g} \mathrm{g}^{-1}$ (S2), maximum values occurred near the mouth of the Coreaú River Estuary. On the other hand, the De-P concentrations ranged from 52.7 (S5) to $68.6 \mu \mathrm{g} \mathrm{g}^{-1}$ (S2), with the lowest variation. Similarly, \% TOC presented a slightly variation from 3.6 (S3) to $4.0 \%$ (S1).

Table 2 - Concentrations of $P$ forms $\left(\mu \mathrm{g} \mathrm{g}^{-1}\right)$ and \%TOC in surface sediments of the Coreaú River Estuary.

\begin{tabular}{|c|c|c|c|c|c|c|c|}
\hline & Exch-P & Fe-P & Ca-P & De-P & Org-P & Total-P & $\% \mathrm{TOC}$ \\
\hline $\mathrm{S} 1$ & 94.9 & 136.9 & 84.2 & 50.7 & 95.4 & 462.1 & 4.0 \\
\hline $\mathrm{S} 2$ & 109.2 & 238.9 & 99.7 & 68.6 & 117.0 & 633.4 & 3.9 \\
\hline S3 & 70.8 & 93.6 & 61.0 & 40.5 & 83.2 & 349.1 & 3.6 \\
\hline $\mathrm{S} 4$ & 122 & 109.1 & 61.0 & 58.5 & 136.6 & 487.2 & 3.7 \\
\hline S5 & 58.7 & 121.4 & 53.3 & 53.3 & 107.6 & 394.3 & 3.8 \\
\hline Mean & 91.1 & 140.0 & 71.8 & 54.3 & 108.0 & 465.2 & 3.8 \\
\hline SD & 26.3 & 57.5 & 19.4 & 10.3 & 20.5 & 108.7 & 0.2 \\
\hline
\end{tabular}

Exch-P: Exchangeable-P; Fe-P: iron-bound-P; Ca-P: authigenic apatite + $\mathrm{CaCO}_{3}$-bound P + biogenic apatite; De-P: detrital-P; Org-P: organic-P; SD: standard deviation.

The predominant $\mathrm{P}$ forms in surface sediments were the labile forms Fe-P, Org-P and Exch-P, which indicate a high potential to eutrophication of the Coreaú River Estuary, as labile sedimentary $\mathrm{P}$ can easily return to the soluble phase. Sedimentary Fe-P has been considered an important environmental indicator of nutrient contamination, as high concentrations are usually attributed to anthropogenic activities (HOU et al., 2013). No strong linear correlation between Fe-P and
Exch-P was observed $(\mathrm{r}=0.389 ; \mathrm{p}<0.05)$, suggesting that these forms could have different sources. Fe-P probably act as the preferential form for $\mathrm{P}$ sinking in the Coreaú River Estuary. The Exch-P fraction can be derived from the DIP adsorbed in silt or clay, oxides and hydroxides (CHEN et al., 1973). The highest Exch-P concentrations observed in Coreaú River Estuary were found at S4, closer to the outfall of shrimp farm effluents. 
The Org-P fraction is usually associated with natural terrestrial inputs of organic matter and biological processes, but anthropogenic activities have contributed significantly to the increase of Org-P in coastal waters (ZHUANG et al., 2014). This is consistent with the relatively higher Org-P concentrations observed throughout the estuary. The release of large amounts of organic matter from the effluents is considered one of the main pollution problems generated by the shrimp farms (PÁEZ-OSUNA, 2001). A strong correlation between Org-P and Exch-P ( $\mathrm{r}=$ $0.706, p<0.05)$ suggests the same main $P$ source.

The Ca-P fraction comprises authigenic apatite (carbonate fluorapatite), biogenic hydroxyapatite (present in bones, teeth and fish scales) and $\mathrm{CaCO}_{3}$-bound P (RUTTENBERG, 1992). Its distribution along the estuary evidenced a marine influence, with highest concentrations near the mouth and a decrease upward the estuary. A similar pattern has been observed in other environments, e.g. Florida Bay and Jaguaribe River Estuary (ZHANG et al., 2004, MARINS et al., 2007). De-P is derived from apatite of metamorphic origin (RUTTENBERG, 1992) and is usually related to the continental inputs and rock weathering, making an additional tracer for terrigenous material (RUTTENBERG; BERNER, 1993). For the samples from the Coreaú River Estuary, the maximum De-P concentration was observed at site S2 and could signal the continental contribution from the urbanized area. However, the high correlation $(r=0.827$, $\mathrm{p}<0.05)$ between Fe-P and De-P suggests a moderate continental contribution and favorable conditions for the formation of these fractions (MARINS et al., 2007).

Nearly constant values were observed for \% TOC, which could be a behavior associated with the mangrove vegetation debris predominating throughout the estuary. Black $e t$ al. (2012) carried out a study with sediments in the Gulf of Eilat (Israel) on the organic inputs of fish farm and verified similar \% TOC values, 4.7 - 6.8, and the highest percentage were attributed to the proximity to the wastewater from fishponds.

\subsection{GRANULOMETRY AND \%TOC IN THE SEDIMENT CORES}

Granulometry and \% TOC data are presented in Figure 2. The sediment grain size composition for $\mathrm{T} 1$ was mostly represented by fine sand, while $\mathrm{T} 2$ was predominantly composed by clay, except between the intervals from 18 to $24 \mathrm{~cm}$ for which fine and medium sand also occurred. $\mathrm{T} 1$ presented a wider \% TOC range $(1.70-3.70 ; 2.50 \pm 0.80)$, whereas $\mathrm{T} 2$ showed higher and constant values $(3.60-3.90 ; 3.80 \pm 0.09)$ with depth. These observations agree with the hydrodynamics of the $\mathrm{T} 1$ and $\mathrm{T} 2$ locations, respectively, at the mouth and the inner estuary.

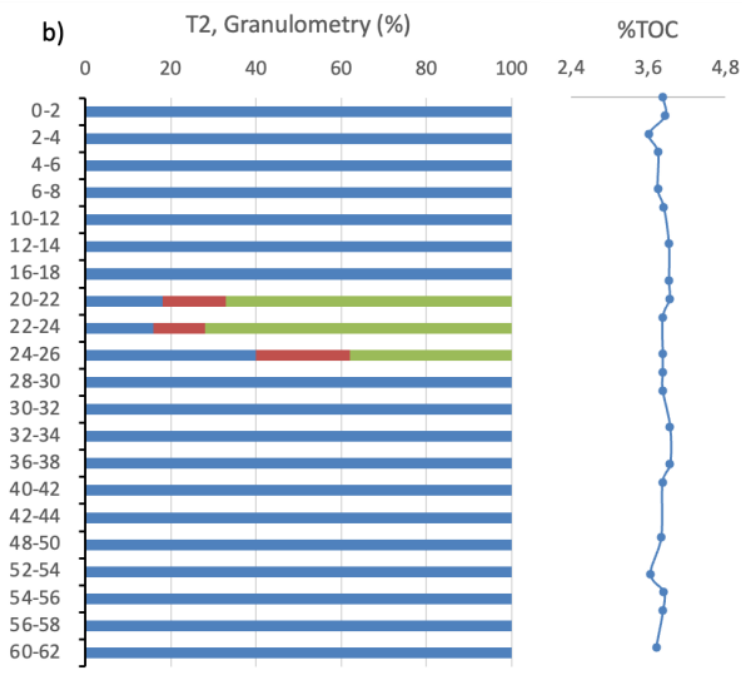




\subsection{VERTICAL DISTRIBUTION OF P FORMS AND DEPOSITIONAL HISTORY}

Sedimentation rate was calculated as $1 \mathrm{~cm}$ $\mathrm{y}^{-1}$ for T1 (RODRIGUES, 2014) which allowed the reconstruction of the depositional records for P from 1954 until 2012 (Fig. 3). The same approach was not applied for T2 due to interferences in the rate calculation, probably as a result of the proximity of small channels and effluents (RODRIGUES, 2014). Total-P concentrations along the core ranged from $234.0-547.4 \mu \mathrm{g} \mathrm{g}^{-1}$ for $\mathrm{T} 1$ and from $389.3-$ $693.9 \mu \mathrm{g} \mathrm{g}^{-1}$ for $\mathrm{T} 2$. The most abundant $\mathrm{P}$ form for T1 was De-P $\left(38.5-278.5 \mu \mathrm{g} \mathrm{g}^{-1}\right)$, which accounted for $36 \%$ of the Total-P, whereas for

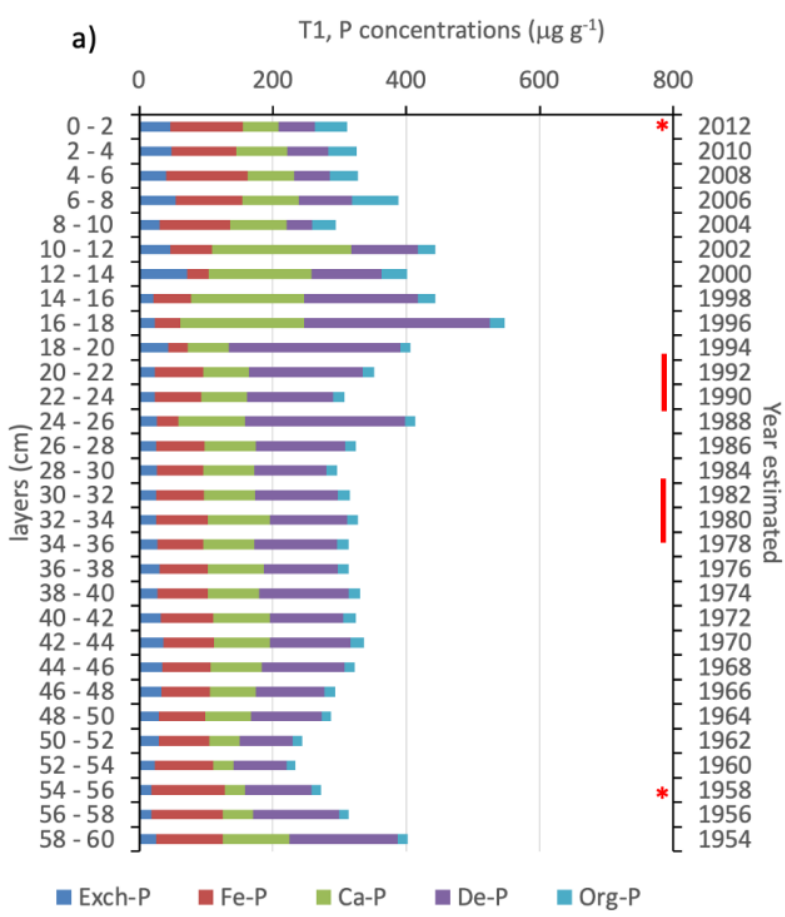

T2, this fraction corresponded to $23 \%$ (44.3 $316.9 \mu \mathrm{g} \mathrm{g}^{-1}$ ). The Fe-P concentrations along the cores ranged from $28.8-121.7$ (22\% in $\mathrm{T} 1)$ and $44.3-316.9 \mu \mathrm{g} \mathrm{g}^{-1}$ (31\% in T2). The concentrations of Ca-P were found from 30.2 $208.3(25 \%$ in $\mathrm{T} 1)$ and $30.2-185.1 \mu \mathrm{g} \mathrm{g}^{-1}$ (17\% in T2). Org-P showed concentrations between 13.0 - 69.4 (7\% in T1) and $85.3-$ $129.4 \mu \mathrm{g} \mathrm{g}^{-1}$ (21\% in T2). The less abundant form was Exch-P with concentrations from $18.6-71.7 \mu \mathrm{g} \mathrm{g}^{-1}(9 \%$ in $\mathrm{T} 1)$ and $27.1-67.2$ $\mu \mathrm{g} \mathrm{g}^{-1}$ (9\% in T2).

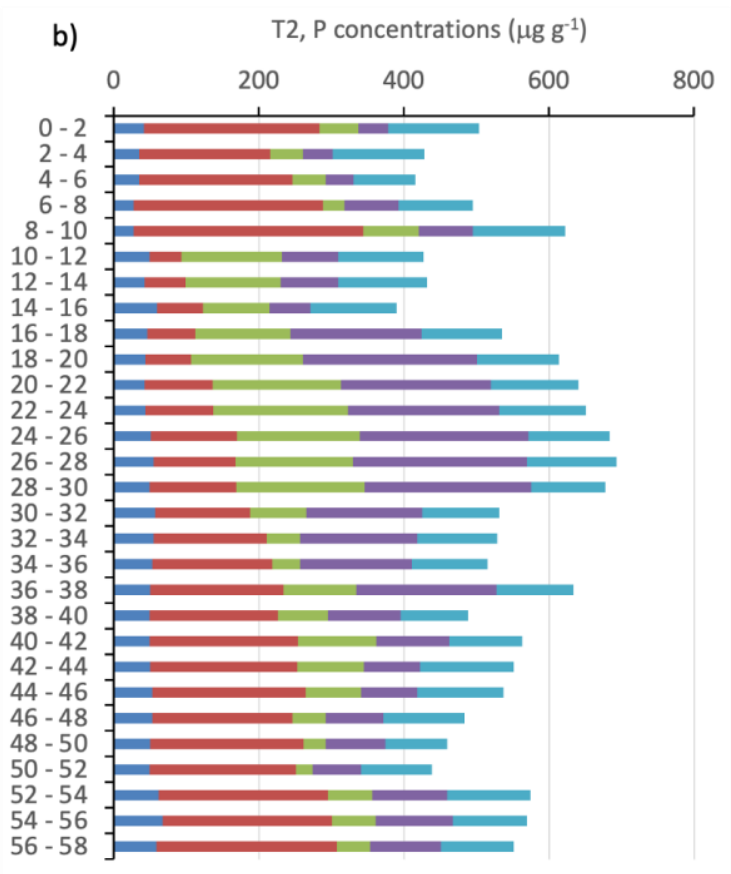

Figure 3

Vertical distribution of P forms in sediment cores of the Coreaú River Estuary. a) T1: at the mouth of the estuary; b) T2: upper estuary. ${ }^{*}$ indicates extreme droughts and red line indicate sequence of years with low precipitation (Nunes; Medeiros, 2020); Exch-P: Exchangeable-P; Fe-P: iron-bound-P; Ca-P: authigenic apatite $+\mathrm{CaCO}_{3}$-bound $\mathrm{P}+$ biogenic apatite; De-P: detrital-P; Org-P: organic-P.

Sediments with smaller particles are expected to present higher efficiency in adsorbing $\quad \mathrm{P} \quad$ (ANDRIEUX-LOYER; AMINOT, 2001). Nevertheless, Total-P did not show significant correlation with fine particles $(r=-0.095, p<0.05)$. For $\mathrm{T} 1$, lower Total-P concentrations together with sandy sediments were found, which can be explained by the stronger hydrodynamics (wave and tidal currents) at that site causing sediment resuspension and increased tendency of $\mathrm{P}$ release to the overlying water, as predicted in other studies (ZHANG et al., 2004).

For T1, the maximum De-P levels (16 - 18 and $24-26 \mathrm{~cm}$ depth layers) could be an indication of the changes in the land that revolved the soil for the construction of shrimp farms and expansion of the urbanization areas, which were reported to happen in the early 1990s (VALENTI et al., 2021), and coincide with our estimated periods (Fig. 3). For T2, enhanced concentrations of De-P (from 16 to $30 \mathrm{~cm}$ depth) and Ca-P (10 - $30 \mathrm{~cm}$ depth) could be related to precipitation changes, as the area has undergone isolated and sequential years of extreme droughts (NUNES; MEDEIROS, 2020).

An increase in Fe-P concentrations could be a signal of high primary productivity or eutrophication of the ecosystem (GONSIORCZYK et al., 1998). In both cores, higher Fe-P concentrations were observed at the top $10 \mathrm{~cm}$, 
and were more pronounced in $\mathrm{T} 2$, which could be caused by the increase of the activities in the shrimp farms in estuary. The increment of $\mathrm{Fe}-\mathrm{P}$ in the deepest and oldest layers in $\mathrm{T} 2$ indicates that the preterit $\mathrm{P}$ sources were mostly natural, probably a contribution from runoff, groundwater and intensification of erosion processes during the mangrove evolution.

The distribution of Ca-P was similar in both sediment cores, with increased concentrations with depth which is a trend intensified by diagenetic processes, e. g. decomposition of organic matter and Fe-P desorption (SLOMP et al., 1996). An opposite behavior for Ca-P and $\mathrm{Fe}-\mathrm{P}$ fractionation was observed for both cores.

Org-P concentrations were five-fold higher for $\mathrm{T} 2$ in comparison with $\mathrm{T} 1$, indicating that the mangrove vegetation plays an important role in $\mathrm{P}$ cycling. Smaller particle sediments, predominating in $\mathrm{T} 2$, have a greater capacity to adsorb Org-P (ZHANG et al., 2010). The
$\%$ TOC vertical profile followed a similar pattern of Org-P, except for the $0-10 \mathrm{~cm}$ depth in $\mathrm{T} 1$, for which an increase in the \% TOC could indicate contributions from a more recent use of the mangrove area. Furthermore, effluents from the city and shrimp farms could have caused augmented $\mathrm{P}$ concentrations, as recent sediment layers of $\mathrm{T} 1$ present higher $\mathrm{P}$ concentrations.

Exch-P presented higher concentrations in the top layers and decreased with depth in T1. The enhancement of Exch-P concentration at deeper sediments may be associated with the $\mathrm{P}$ release from calcium carbonate crystals (WANG et al., 2013). Conversely, as well as in surface sediments, significant positive correlations between Exch-P and Org-P ( $\mathrm{r}=$ $0.605, \mathrm{p}<0.05)$, and among Exch-P and $\%$ TOC $(\mathrm{r}=0.762, \mathrm{p}<0.05)$ were observed. This indicates that the mineralization of organic matter is an important phase in the $\mathrm{P}$ cycling in the Coreaú River Estuary.

\subsection{SEDIMENT QUALITY ASSESSMENT BASED ON TOTAL-P CONCENTRATIONS}

The Total-P data observed in the surface sediments and the core samples comprising the $0-2 \mathrm{~cm}$ interval were used to evaluate the sediment quality of the Coreaú River Estuary, by comparison with some proposed indices and data from other estuaries (Table 3). Persaud et al. (1993) developed a guide for the evaluation of sediment contamination for Canada's lakes and established a limit for Total-P concentration of $600 \mu \mathrm{g} \mathrm{g}^{-1}$ as a reference for a low contamination degree. According to these researchers, values higher than the background reference highlight the need for monitoring and management of eutrophication processes. In the Coreaú River Estuary, the mean Total-P concentration was $445 \mu \mathrm{g} \mathrm{g}^{-1}$, which classify the estuary as "No Effect Level". Robertson and Stevens (2013) established techniques for the monitoring and management of coastal and estuarine environments in New Zealand using a range of parameters including Total-P concentrations, which classify the sediments of the Coreaú River Estuary in the "good quality" threshold. However, a five-year monitoring period is recommended to follow the settlement trends of the natural background levels.

Table 3 - Proposed values for sediment quality assessment and the mean concentrations of Total-P ( $\mathrm{gg}$ $\left.\mathrm{g}^{-1}\right)$ in impacted aquatic environments.

\begin{tabular}{lcl}
\hline Region & Total-P & Reference \\
\hline Great Lakes (Canada) & 600 & PERSAUD et. al. (1993) \\
New River Estuary (New Zealand) & $<500$ & ROBERTSON; STEVENS (2013) \\
Provinces of Guayas, El Oro, & 898 & SONNENHOLZNER; BOYD (2000) \\
Zhujiang (Pearl) River Estuary & 878 & WANG et. al. (2013) \\
Acaraú River Estuary (Brazil) & 1624 & NÓBREGA et. al. (2014) \\
Coreaú River Estuary (Brazil) & 445 & This study \\
\hline
\end{tabular}

\section{CONCLUSIONS}

We investigated the sedimentary $P$ distribution in an estuarine area under the influence of shrimp farms. The predominance of Exch-P, Fe-P and Org-P, and the high $\%$ TOC in surface sediments indicated an eutrophication potential of the Coreaú River Estuary. The Org-P contents, although naturally high, could be derived from anthropic activities, as such fraction was found at high levels at surface sediments close to the farms 
and the city effluents. The distribution of Total-P and sedimentation rates indicated that the construction and beginning or maximum activity periods of the shrimp farms occurred at the end of the 1980 and mid-1990, coinciding with other records. These observations were also supported by the maximum concentrations of De-P and Fe-P fractions, contrasting with the increment of De-P in deepest layers which were associated

\section{ACKNOWLEDGMENTS}

We acknowledge the National Counsel of Technological and Scientific Development (CNPq) for the scholarship grant to R. Aquino while at the PPGG/UFPA and the financial

\section{REFERENCES}

ABCC. Associação Brasileira de Criadores de Camarão. Revista da ABCC. 21(2):1-68, 2019. Available at:

https://abccam.com.br/2019/11/revistaabcc-especial-fenacam19-ano-xxi-n-02/

ANDRIEUX-LOYER, F.; AMINOT, A. Phosphorus forms related to sediment grain size and geochemical characteristics in French Coastal areas. Estuarine, Coastal and Shelf Science 52: 617-629, 2001

BLACK, K.D.; CALDER, L.A.; NICKELL T.D.; SAYER, M.D.J.; ORR, H.; BRAND, T.; COOK, E.J.; MAGILL, S.H.; KATZ, T.; EDEN, N.; JONES, K.J.; TSAPAKIS, M.; ANGEL, D. Chlorophyll, lipid profiles and bioturbation in sediments around a fish cage farm in the Gulf of Eilat, Israel. Aquaculture 317-327, 2012

BOSTROM, B.; ANDERSEN, J.M.; FLEISCHER, S.; JANSSON, M. Exchange of phosphorus across the sediment-water interface. Hydrobiologia 170:229-244, 1988

CHEN, Y.S.R.; BUTLER, J.N.; STUMM, W. Kinetic study of phosphate reaction with aluminum oxide and kaolinite. Environmental Science \& Technology 7: 327-332, 1973

FAO. The State of World Fisheries and Aquaculture 2014. FAO Fisheries and Aquaculture Department, Rome, 223 p., 2014

FILLIPELLI, G. M.; DELANEY, M. L. Phosphorus geochemistry of equatorial Pacific sediments. Geochimica et Cosmochimica Acta 60(9):1479-1495, 1996 to preterit $\mathrm{P}$ sources to the estuary, mostly natural. According to the Total-P concentrations in the surface sediments and sediment quality guidelines, the estuary can be classified as unpolluted. Nevertheless, we recommend a monitoring of the estuarine area in view of the potential eutrophication risk, as indicated by the predominance of labile $\mathrm{P}$ fractions.

support provided by the Coordination for the Improvement of Higher-Level Personnel (CAPES) for the Project CAPES-Ciências do Mar-Proc.0876/10.

GAUDETTE, H. E.; FLIGHT, W. R; TONER, L.; FOLGER, D. W. An inexpensive tritation method for the determination of organic carbon in recent sediments. Journal of Sedimentary Petrology 44(1):249-253, 1974

GONSIORCZYK, T.; CASPER P.; KOSCHEL, R.. Phosphorus-binding forms in the sediment of an oligotrophic and an eutrophic hardwater lake of the Baltic Lake District (Germany). Water Science and Technology 37:51-58, 1998

HANSEN, H.P.; KOROLEFF, F. Determination of nutrients In: Grasshoff K., Kremling K., Ehrhardt M. (eds.) Methods of Seawater Analysis Wiley-VCH, 159228, 1999

HOU, D.; HE, J.; LU, C.; DONG, S.; WANG, J.; XIE, Z.; ZHANG, F.. Spatial variations and distributions of phosphorus and nitrogen in bottom sediments from a typical north-temperate lake, China. Environmental Earth Sciences 71:3063-3079, 2013

HUERTA-DIAZ, M.A.; TOVAR-SÁNCHEZ, A.; FILIPPELLI, G.; LATIMER, J.; SAÑUDO-WILHEMY, S.A. A combined CDB-MAGIC method for the determination of phosphorus associated with sedimentary iron oxyhydroxides. Applied Geochemistry 20:2108-2115, 2005

IBAMA-MMA. Instituto Brasileiro do Meio Ambiente e dos Recursos Naturais Renováveis - Ministério do Meio Ambiente. Diagnóstico da Carcinicultura do Estado do Ceará. 2005. Available in 
http://www.mma.gov.br, viewed in July 15, 2012.

LACERDA, L. D.; MOLISANI, M.M.; SENA, D.; MAIA, L.P. Estimating the importance of natural and anthropogenic sources on $\mathrm{N}$ and $\mathrm{P}$ emission to estuaries along the Ceará State Coast NE Brazil. Environmental Monitoring and Assessment 141:149-164, 2008

MARINS, R.V.; PAULA FILHO, F.J.; ROCHA, C.A.S.. Geoquímica de fósforo como indicadora da qualidade ambiental e dos processos estuarinos do rio Jaguaribe costa nordeste oriental brasileira. Química Nova 30:1208-1214, 2007

MCKELVIE, I.D. Separation, Preconcentration and Speciation of Organic Phosphorus in Environmental Samples. In: Turner B. L., Frossard E., Baldwin D. S. (eds.) Organic Phosphorus in the Environment. CABI Publishing, 1-20, 2005

MOLISANI, M.M.; CRUZ, A.L.V.; MAIA, L.P. Estimativa da descarga fluvial para os estuários do Ceará, Brasil. Arquivos de Ciências do Mar 39:53-60, 2006

NITTROUER, C.A.; STERNBERG, R.W.; CARPENTER, R.; BENNETT, J.T.. The use of $\mathrm{Pb}-210$ geochronology as a sedimentological tool: Application to the Washington continental shelf. Marine Geology 31:297-316, 1979

NÓBREGA, G.N.; OTERO X.L.; MACÍAS, F.; FERREIRA, T.O. Phosphorus geochemistry in a Brazilian semiarid mangrove soil affected by shrimp farm effluents. Environmental Monitoring and Assessment 1865749-5762, 2014

NUNES, L.F.C.V.; MEDEIROS, P.H.A. Análise histórica da severidade de secas no Ceará: efeitos da aquisição de capital hidráulico sobre a sociedade. Revista de Gestão de Água da América Latina $17: \mathrm{e} 18$, 2020 https://dx.doi.org/10.21168/rega.

PAÉZ-OSUNA, F. The environmental impact of shrimp aquaculture: causes, effects and mitigating alternatives. Environmental Management 28:131-140, 2001

PEEL, M.C.; FINLAYSON, B.L.; MCMAHON, T.A. Updated world map of the Köppen-Geiger climate classification. Hydrology and Earth System Sciences 11:1633-1644, 2007

PERSAUD, D.; JAAGUMAGI, R.; HAYTON, A. Guidelines for the Protection and Management of Aquatic Sediment
Quality in Ontario. Ministry of Environment and Energy, Ontario, 39 p., 1993

ROBERTSON, B.M.; STEVENS, L.M. New River Estuary - Fine Scale Monitoring of Highly Eutrophic Arms 2012/2013. Report prepared by Wriggle Coastal Management for Environment Southland, 35 p., 2013

RODRIGUES, S.W.P. 2014. Detecção de mudança e sedimentação no Estuário do Rio Coreaú. PhD thesis. Programa de PósGraduação em Geologia e Geoquímica; Universidade Federal do Pará. 49p.

RUTTENBERG, K.C. Development of a sequential extraction method for different forms of phosphorus in marine sediments. Limnology and Oceanography 37:14601482, 1992

RUTTENBERG, K.C.; BERNER, R.A. Authigenic apatite formation and burial in sediments from non-upwelling, continental margin environments. Geochimica et Cosmochimica Acta 57:991-1007, 1993

SAMADI-MAYBODI, A.; TAHERI SAFFAR, H.; KHODADOUST, S.; NASROLLAHZADEH SARAVI, H.; NAJAFPOUR, S. Study on different forms and phosphorus distribution in the coastal surface sediments of Southern Caspian Sea by using UV-Vis spectrophotometry. Spectrochimica Acta Part A: Molecular and Biomolecular Spectroscopy 113:6771,2013

SLOMP, C.P.; EPPING, E.H.G.; HELDER, W.; RAAPHORST, W.V. A key role for iron-bound phosphorus in authigenic apatite formation in North Atlantic continental platform sediments. Journal of Marine Research 54:1179-1205, 1996

SONNENHOLZNER, S., BOYD, C.E., Chemical and physical properties of shrimp pond bottom soils in Ecuador. Journal of the World Aquaculture Society 31(3):358-37, 2020.

VALENTI W. C.; BARROS, H.P.; MORAESVALENTI, P.; BUENO, G.W.; CAVALLI, R.O. Aquaculture in Brazil: past, present and future. Aquaculture Reports 19:100611, 2021

WANG, L.; YE, M.; LI, Q.; ZOU, H.; ZHOU, Y. Phosphorus speciation in wetland sediments of Zhujiang (Pearl) River Estuary, China. Chinese Geographical Science 23:574-583, 2013

ZHANG, J.Z.; FISCHER, C. J.; ORTNER, P.B. Potential availability of sedimentary 
phosphorus to sediment ressuspension in Florida Bay. Global Biogeochemical Cycles, 18:1-14, 2004

ZHANG, J.Z.; GUO, L.; FISCHER, C. J. Abundance and chemical speciation of phosphorus in sediments of the Mackenzie River Delta, the Chukchi Sea and the Bering Sea: Importance of Detrital Apatite. Aquatic Geochemistry 16:353-371, 2010
ZHUANG, W.; GAO, X.; ZHANG, Y.; XING Q.; TOSI, L.; QIN, S. Geochemical characteristics of phosphorus in surface sediments of two major Chinese mariculture areas: The Laizhou Bay and the coastal waters of the Zhangzi Island. Marine Pollution Bulletin 83:343-351, 2014 